\title{
The Access Structure in Learner's Dictionaries*
}

\author{
Mariza Steyn, Unit for Afrikaans, Language Centre, University of \\ Stellenbosch, Stellenbosch, Republic of South Africa (ms@sun.ac.za)
}

\begin{abstract}
Dictionaries have to be compiled in accordance with specific target users and dictionary goals. User orientation is, however, not the only criterion for measuring the success of a dictionary. Present-day lexicography requires the evaluation of the accessibility of dictionaries. The ease with which macro- and microstructural information is located and retrieved determines the quality and accessibility of the presentation. User-orientated, accessible learner's dictionaries can contribute substantially to the improvement of communication in a multilingual South Africa with different groups of language learners.

Metalexicography makes provision for guide structures that facilitate access to information in the dictionary. The outer, inner and meta-access structure are functional structure elements that increase the retrievability of information and help the user to reach, as swiftly as possible, the information he/she is looking for. During the planning of a learner's dictionary, the lexicographer must draw up, among others, a dictionary plan in which a detailed explanation of the outer and inner access structure is given. Such a dictionary plan contributes to a consistent application of lexicographical decisions. Decisions regarding the access structure must also be explained and illustrated in the front text in order to enable learners to acquire dictionary skills and become effective dictionary users.
\end{abstract}

Keywords: METALEXICOGRAPHY, OUTER ACCESS STRUCTURE, INNER ACCESS STRUCTURE, LEARNER'S DICTIONARY, FRAME STRUCTURE, UNINTEGRATED, INTEGRATED, MONO- AND POLY-ACCESSIBLE, OUTER TEXTS, OUTER RAPID ACCESS, DATA DISTRIBUTION STRUCTURE, MICRO-ARCHITECTURE, DATA-ARCHITECTURE, DATA EXPOSURE STRUCTURE, META-ACCESS

Opsomming: Die toegangstruktuur in aanleerderwoordeboeke. Woordeboeke moet saamgestel word met inagneming van 'n spesifieke teikengroep en woordeboekdoel. Gebruikersgerigtheid is egter nie die enigste kriterium waaraan die sukses van 'n woordeboek gemeet word nie. Die hedendaagse leksikografie vereis die beoordeling van die toeganklikheid van 'n woordeboek. Die gemak waarmee makro- en mikrostrukturele inligting opgespoor en ontsluit word, bepaal die kwaliteit en die toeganklikheid van die aanbieding. Gebruikersgerigte toeganklike aanleerderwoordeboeke kan 'n wesenlike bydrae lewer tot die verbetering van kommunikasie in 'n veeltalige Suid-Afrika met verskillende groepe taalaanleerders.

* This article was read as a paper at the Seminar on Learners' Dictionaries presented by the African Association for Lexicography at the University of Pretoria, Pretoria, Republic of South Africa, 11-12 November 2002. It is based on an unpublished M.A. Thesis by Mariza Stark, Die toegangstruktuur in verklarende aanleerderwoordeboeke, accepted in March 2001 by the University of Stellenbosch, Stellenbosch.

Lexikos 14 (AFRILEX-reeks/series: 14: 2004): 275-298 
Die metaleksikografie maak voorsiening vir gidsstrukture wat toegang tot inligting in die woordeboek vergemaklik. Die eksterne, interne en metatoegangstrukture is funksionele struktuurelemente wat die herwinbaarheid van inligting verhoog en die gebruiker help om so vinnig moontlik uit te kom by die verlangde inligting wat hy/sy soek. Die leksikograaf moet tydens die beplanning van 'n aanleerderwoordeboek ' $n$ woordeboekplan opstel waarin onder andere die eksterne en interne toegangstruktuur uiteengesit word. So 'n woordeboekplan dra by tot 'n konsekwente toepassing van leksikografiese besluite. Besluite oor die toegangstruktuur moet ook in die toeligting beskryf en geïllustreer word om aanleerders in staat te stel om woordeboekontsluitingsvaardighede te verwerf en effektiewe woordeboekgebruikers te word.

Sleutelwoorde: METALEKSIKOGRAFIE, EKSTERNE TOEGANGSTRUKTUUR, INTERNE TOEGANGSTRUKTUUR, AANLEERDERWOORDEBOEK, RAAMSTRUKTUUR, GEÏNTEGREER, NIE-GEÏNTEGREER, MONO- EN POLI-TOEGANKLIK, BUITETEKSTE, EKSTERNE KITSTOEGANG, DATAVERSPREIDINGSTRUKTUUR, MIKRO-ARGITEKTUUR, DATA-ARGITEKTUUR, DATABLOOTLEGGINGSTRUKTUUR, METATOEGANG

\section{Introduction}

Recent research in the field of metalexicography has focused on the structure of dictionaries. The following six main structures have been identified by Hausmann and Wiegand (1989): macro-, micro-, distribution, frame, reference and access structure. The access structure can be regarded as the search route the dictionary user follows during a dictionary consultation procedure. Bergenholtz and Tarp (1995: 16) define it as the structure of lexicographical indicators directing the user to the information required. A distinction is made between the outer and inner access structure. The outer access structure leads a user up to the lemma sign, introducing the article from which the needed information is to be retrieved, and the inner access structure guides the user within a dictionary article to the search zone in which the relevant data is presented.

The objective of the first part of this article is to give an overview of the elements which comprise the access structure of a dictionary. These elements of the outer and inner access structure will be illustrated and discussed briefly. Only some aspects of the outer access structure will be dealt with in more depth. Although the focus will be on monolingual learner's dictionaries, examples from bilingual learner's dictionaries will also be included.

\section{What is the correlation between the access structure and the dictionary consultation procedure?}

The access structure is the search route the user follows during a consultation procedure and it correlates directly with the actions taking place during the consultation process. The consultation process therefore affects the access structure of a dictionary. According to Béjoint (1994: 155), the following actions take place when the user consults a dictionary: 
1. Choose the correct dictionary according to the problem.

2. Identify the problem area, word or phrase.

3. Determine the most likely place in the dictionary where the word, phrase is treated.

4. Guess which form of the word is listed as lemma.

5. Guess where the word is placed in the alphabetical order of the dictionary. Here capital letters, geographical words, abbreviations etc. play a role.

6. Find the word in its place as entry or subentry.

7. Interpret the information given in the entry.

Tono (1992: 238) gives a schematic illustration of the consultation procedure:

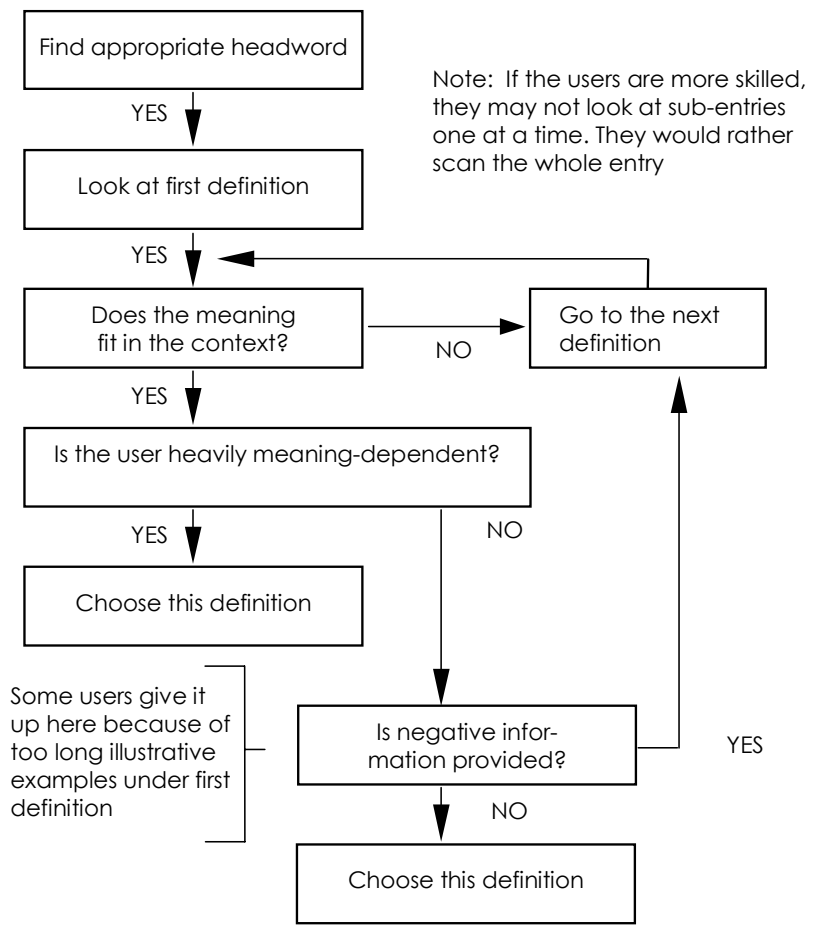

It is evident from both examples that the consultation activities consist of two stages, which correlate directly with the two main structures of the dictionary, namely the macro- and microstructure. By implementing elements of the outer 
access structure, the user can find information in the macrostructure, while the inner access structure leads the user to specific information in the microstructure. The first part of the dictionary consultation procedure where the user follows the outer search path to the desired lemma will now be considered.

\section{The outer access structure of a dictionary}

The outer access structure starts on the cover of the dictionary. Almind and Bergenholtz (2000) have made a detailed study of the aesthetic dimension of the dictionary where the outer access structure includes, for instance, the type and amount of information, as well as the presentation on the back and front pages of the dictionary.

\subsection{The frame structure}

Once the relevant dictionary has been found, the next step is to find the right component in the dictionary. This brings us to the frame structure. Accessibility of data is not only determined by the use of a well-defined access structure, leading the user to a venue within the word list structure of the dictionary, but it is also determined by a functional positioning of the data within the word book structure of the dictionary, by employing different texts in the dictionary to explain and explicate the contents of the dictionary. Utilising a word book approach, a dictionary can display a so-called frame structure (Kammerer and Wiegand 1998: 230, 233). Any dictionary is regarded as a carrier of different texts and text types. The frame structure makes provision for three textual focal points, i.e. the front matter, the central list and the back matter.

The central list is the textual component which is the most typical venue for dictionary consultation procedures. The structure of the central list should therefore facilitate the quick and unimpeded access to the required data. The outer access structure has to guide the user to a specific article stretch within the central list and within the article stretch to a specific lemma sign.

The front matter section contains all the texts preceding the central list and the back matter section contains all the texts following the central list. The texts in the front and back matter of a specific dictionary constitute the outer texts of that dictionary. According to Gouws (2001: 103), neither the front nor the back matter are functional parts of a dictionary, although both may contain individual texts, for instance the users' guidelines, which have specific functions in the dictionary. Traditional dictionaries have often used the front and back matter to present outer texts. However, in many dictionaries these were not functional texts and contributed very little to the genuine purpose of the dictionary. Outer texts included in the front and back matter should help the user to gain access to the required data as swiftly as possible. The user should furthermore be assisted in accessing information included in the outer texts. 


\subsection{Unintegrated and integrated outer texts}

According to Wiegand (1998: 299), every dictionary has a genuine purpose. Outer texts can be classified according to their contribution to the achievement of the genuine purpose of the dictionary. An unintegrated outer text is not integrated into the genuine purpose of the dictionary. However, these unintegrated outer texts can "also serve a purpose as functional texts and they have their own genuine purpose, not identical to that of the dictionary but also important to ensure the eventual successful use of the dictionary" (Gouws 2002: 474). Examples of unintegrated outer texts are the title page, introduction, foreword, etc.

Another example of an unintegrated outer text with its own genuine purpose is the Language Awareness Notes in Macmillan English Dictionary for Advanced Learners. This additional text consists of eleven subtexts and is inserted into the central word list. It functions as a twice partially extended complex outer text. The Language Awareness Notes is preceded by two subtexts: an explanatory note and a table of contents. These secondary outer texts give immediate access to this unintegrated text and encourage the user and teacher to use the language tools included in the main text.

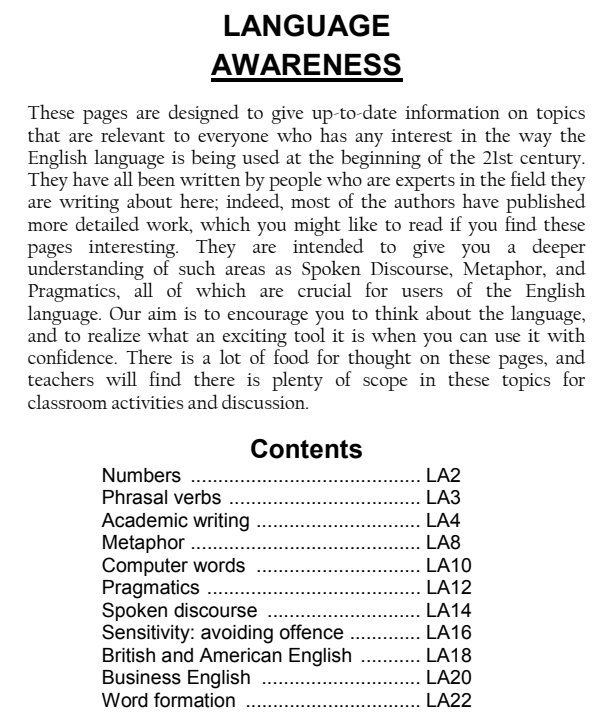

Example 1: Two subtexts preceding an unintegrated text

Integrated outer texts are directed at achieving the genuine purpose of the dictionary. The inclusion of these texts in learner's dictionaries should be expanded because of the added value and contribution to the successful dictionary consultation process. According to Gouws (2002: 473), there are two types 
of integrated texts: "These texts belong either to the class of so-called 'help texts' with the function to assist the user with a more successful dictionary consultation procedure or, in as far as they contain a part of the lexicographic data presented in the dictionary, they are integrated texts from which the user can retrieve information regarding the subject matter of the dictionary."

The users' guidelines text is an example of a help text that assists the user in order to have a successful dictionary consultation procedure. By consulting the users' guidelines, complemented by a sample article, the learner gains insight into the structure and contents of the dictionary.

In order to complement the data presented in the central list a part of the lexicographic data can be accommodated in lists, traditionally presented in the back matter. Grammar codes presented in Longman Dictionary of Contemporary English (LDOCE) are integrated into the distribution of lexicographic data and assist the user in retrieving information regarding the subject matter of the dictionary. The same dictionary also includes a list of geographical names with adjectives forming part of the macrostructure of the dictionary. By adding this extra list with grouped and related words, the lexicographers support information retrieval and enhance language learning.

\subsection{Mono- and poly-accessible dictionaries}

In most general monolingual dictionaries, the central list is the only outer access structure; therefore the macrostructure of these dictionaries coincides with the outer access structure. These dictionaries, classified according to their outer access profile, are mono-accessible dictionaries with only one defined search path to solve the search problem. A learner who consults the mono-accessible Tweetalige Aanleerderswoordeboek/Bilingual Learner's Dictionary (TAW), for the translation of "mountain" uses the following outer search path: he/she finds the letter $M$ and the relevant article stretch, uses the guide words and scans through the partial article stretch for the lemma sign.

Some dictionaries have additional wordlists and/or indexes which form part of the comprehensive macrostructure. In these poly-accessible dictionaries the user may arrive at lexicographical data by using more than one defined search path. Poly-accessible dictionaries only have one macrostructure but more than one access structure. The following example illustrates the different search paths available to the user:

A learner using the Oxford Advanced Learner's Dictionary (OALD) has two options in solving the search problem in reaching "mountain". Firstly, the

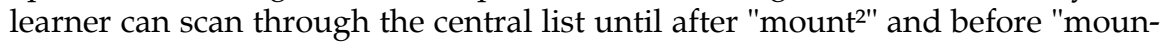
tainside". Another option is to use Appendix 10, Defining Vocabulary to identify the lemma ("mountain") and then move along the outer search path to the lemma in the central list. The learner can therefore first confirm whether a specific word is listed and used without having to scan through multiple article 
stretches. This word list also gives an overview of the macrostructural scope of the dictionary.

Another example of an outer text creating a poly-accessible dictionary is the extra wordlist provided in Collins COBUILD Learner's Dictionary (COBUILD) as a text in the back matter. In this outer text, the usage frequency of the lemmata is indicated and as an extra access structure adds value for the beginner who uses/learns the most frequent words in English. The list of geographical names in the same dictionary does not, however, make the dictionary poly-accessible, since the names are not listed in the central list. It is an unintegrated text aimed at the systematizing of information to enhance knowledge transfer.

The German learner's dictionary Wörterbuch Deutsch als Fremdsprache (WDAF) uses outer texts to rectify the unnatural alphabetical placing of, in Bolinger's words (1985: 69) "carrots, onions, beetroot and salsify next to one another". The lexicographers provide lists with words belonging to the same semantic fields. The learner can, for instance, find a grouping of words relating to physical processes. These functional texts presented in the outer text not only place words in their specific context, but also create a poly-accessible dictionary, giving the learner accessible search path options. The poly-accessibility of this dictionary also functions in another direction. Many articles contain reference entries with sections in the outer text (Wortfelder) as reference addresses. The alphabetical ordering of the central list is complemented by the semasiological ordering in the outer text (Gouws 2002: 480-481).

\section{Wortfelder I.: Der Mensch}

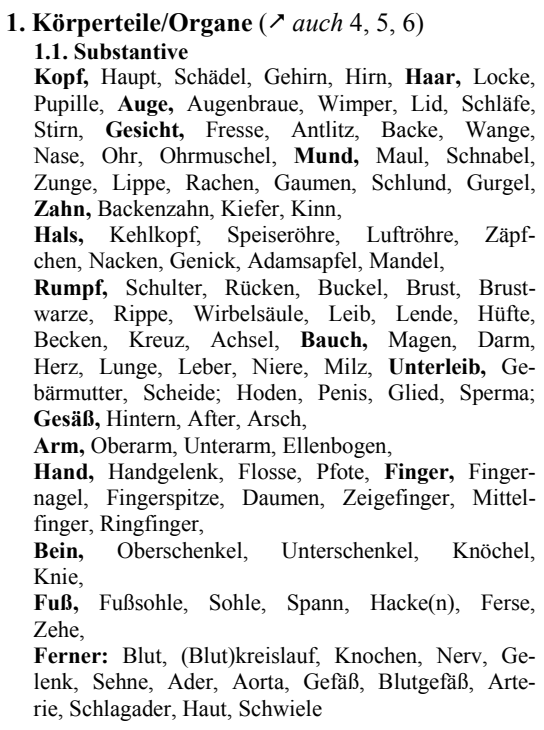




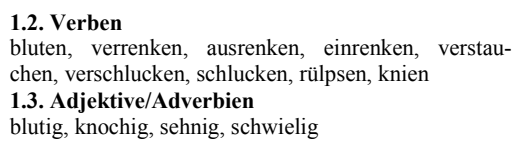

Example 2: Semantic fields in the back matter of WDAF

In order to help the learner to organize and memorize words, the same dictionary gives tables in which grammatical information is grouped together. Words which belong to the same semantic, morphological and syntactic groups are presented together to give the learner an image of the language. These texts create other access possibilities for the user and contribute to a user-friendly dictionary.

\section{Tafel V}

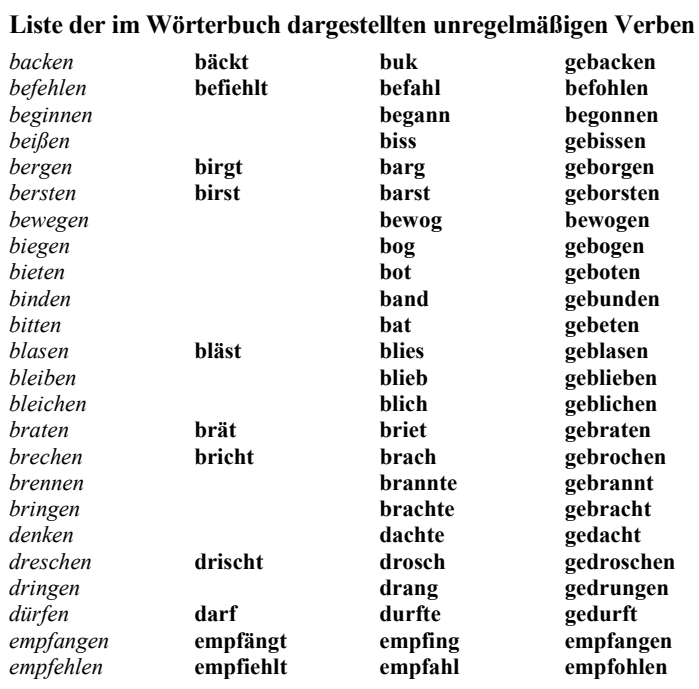

Example 3: List in the back matter of WDAF

All these examples illustrate the poly-accessibility of dictionaries in terms of the word list structure, thus an enhanced access to the central list.

\subsection{Primary and secondary outer texts}

According to Hausmann and Wiegand (1989: 331), each dictionary should contain two compulsory texts, i.e. the central list, which presents the lemmata as macrostructural entries and primary treatment units, and an outer text, usually presented in the front matter, with the users' guidelines. This text already has an access function because it not only informs users of the data collection in the 
dictionary, but also explicates the positioning and arrangement of data types. This allows the user a more rapid dictionary consultation procedure. A typical component of such a users' guidelines text is a sample article taken from the central list to illustrate the default article structure, micro-architecture and search zones.

The users' guidelines function as an immediate constituent of the dictionary as a whole. The front matter text presenting the table of contents of the dictionary also falls in this category. Both can be regarded as first order primary outer texts. The table of contents gives access to most of the elements of the word book structure and occasionally to parts of these elements. Where the typical outer access structure guides a user to a lemma sign, the table of contents includes entries which guide the user to the different components of the frame structure and to the individual texts contained in these components of the dictionary as a big text. The functional value of a table of contents, which increases the accessibility of the dictionary, may never be underestimated.

OALD and COBUILD both include tables of contents which give access to other lists and information in the front and back matter. Once again the learner can follow two search paths, i.e. the direct route to the required information or rapid access by means of the table of contents. The lexicographer must also ensure accessibility to the outer texts.

The users' guidelines of some learner's dictionaries focus only on explicating the data presented in the central word list. It therefore functions not as an immediate constituent of the dictionary as a whole, but as an immediate constituent of the extended central list. Such an outer text functions as a second order primary outer text. Another example of an outer text which is a constituent only of the central word list is the list of defining vocabulary. It increases the access possibilities and focuses on data presented in the central list text.

Many dictionaries contain primary outer texts with their own outer texts, e.g. an explanatory text, a table of contents or a users' guidelines text directed not at the dictionary as such but only at a specific outer text. These texts are complex outer texts that are extended by adding subtexts. The subtexts function as secondary outer texts and are not immediate constituents of the dictionary as a big text but rather of the specific outer texts. A major function of secondary outer texts is to provide access to their primary outer texts and to increase accessibility to data accommodated outside the central list of a dictionary.

In WDAF a secondary text refines access to the texts in the back matter of the dictionary. The lexicographers provide a classification of all the semantic fields listed in the back matter. This secondary text places all the semantic fields in context and facilitates the search and learning processes. A table of contents with page references gives quick access to texts in the back matter. This functional secondary text increases the accessibility and retrievability of information and is a good example of special extended access to an outer text. 


\section{Tafeln}

(Übersicht)

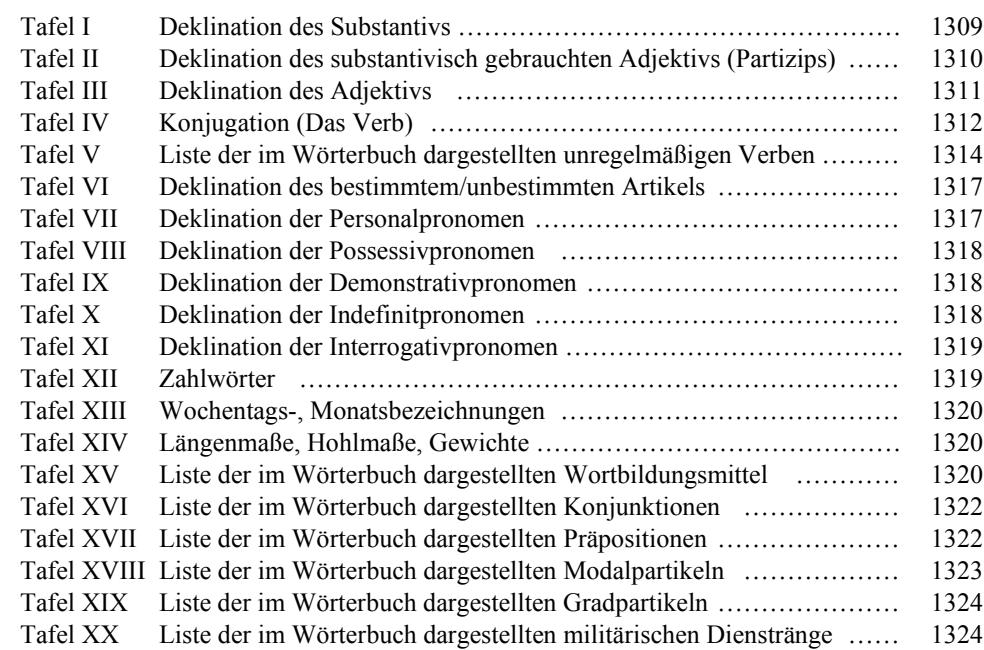

Example 4: Access to outer texts

LDOCE bridges the traditional bias directed at the central word list and employs an outer text in the front matter to familiarise users with the structure of the users' guidelines. This secondary text is an attempt to enhance the access to the compulsory and important text that explains the system of the dictionary. It forms part of a more sophisticated access structure which is the key to a successful lexicographic product.

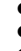
Guide to the Dictionary

xiv

\begin{tabular}{|c|c|c|c|}
\hline \multicolumn{3}{|c|}{ Contents } & \multirow{2}{*}{$\begin{array}{l}1 \text { How to find the word you are } \\
\text { looking for }\end{array}$} \\
\hline 1 & How & to find what you are looking for & \\
\hline & & Compound words & \multirow{2}{*}{$\begin{array}{l}\text { Words are listed in this dictionary in alphabetical } \\
\text { order }\end{array}$} \\
\hline & 1.2 & Phrasal verbs & \\
\hline & 1.3 & Derived words without definition & Compound words \\
\hline & 1.4 & Homographs & \multirow{6}{*}{$\begin{array}{l}\text { Compound words are groups of two or more words } \\
\text { with a fixed form and a special meaning, such as } \\
\text { front man and front line. Most of these are } \\
\text { shown as full headwords (but see section } 1.6 \\
\text { Phrases and idioms). They are treated like ordinary } \\
\text { words in the alphabetical order; the space or } \\
\text { hyphen between the two parts is ignored. }\end{array}$} \\
\hline & & Other types of headwords & \\
\hline & & Phrases and idioms & \\
\hline \multirow[t]{7}{*}{2} & Uno & erstanding meaning & \\
\hline & 2,1 & Words with more than one meaning & \\
\hline & 2.2 & Definitions & \\
\hline & 2.3 & Examples & \multirow{4}{*}{$\begin{array}{l}\text { front-al } \\
\text { frontal sys-tem } \\
\text { front-and-center } \\
\text { front bench } \\
\text { front-bench·er }\end{array}$} \\
\hline & 2.4 & Collocations & \\
\hline & 2.5 & Finding the meaning you want - Signposts & \\
\hline & 2.6 & Long entries with menus & \\
\hline
\end{tabular}


because of a more advanced language knowledge of the users or because of space considerations, they must be marked by non-typographical markers and treated consistently.

The following examples illustrate possible external access problems that users might experience because of an inaccessible placement of sublemmata.

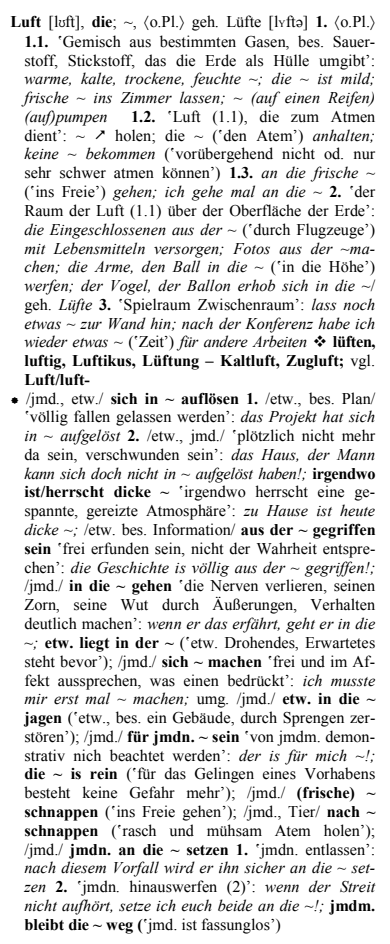

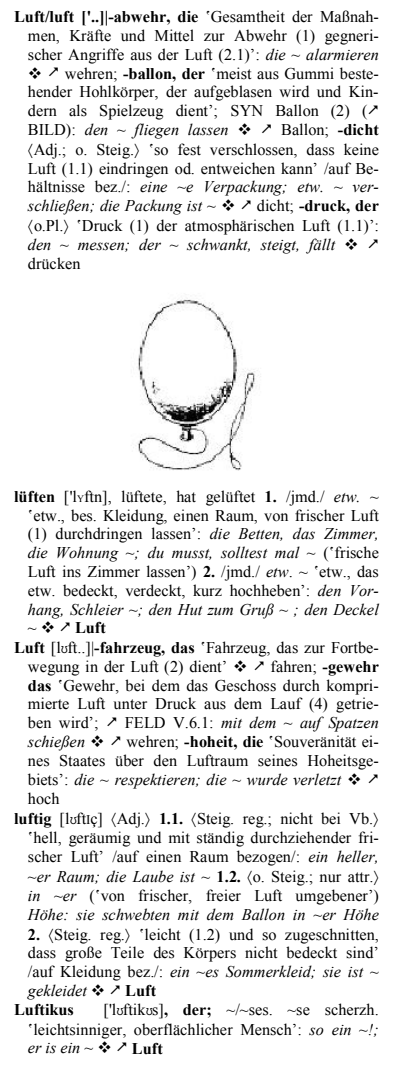

Luft/luft [luft..]-kissenfahrzeug [kssn..], das 'Fahrzeug, dessen unterer Teil, ählich einem Kissen, mit komprimierter Luft gefüllt ist und sich dicht über schnell fortbewegt' $\$>$ Kissen, $>$ fahren; - -landetruppe [landa..], die 'Truppe, die mit Flugzeugen (hinter der gegnerischen Front) abgesetzt wird, um am Boden zu kämpfen' $*>$ landen, ' Truppe; -leer 〈Adj;; o. Steig.; vorw. attr.〉 'keine Luft enthatend, ein Vakuum bildend': ein $\sim e r$ Raum; ein

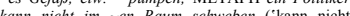
ohne enge Verbindung mit der Realität leben') $\$$ $>$ leer; -linie, die $\langle 0 \mathrm{Pl}\rangle$ ' 'burzeste Entfernung zwischen zwei Punkten auf der Oberfläche der Erde': die zwischen Berlin und Paris beträgt nur etwa $900 \mathrm{~km}$ * > Linie; -matratze, die 'großes Kissen von etwa zwei Meter Lange, das aufgeblasen wird und zum Liegen, Schlafen verwendet wird": die die 'Beförderung der Post, Fracht durch Flugzeuge': einen Brief, ein Paket per $\sim$ absenden, befordern *'> Post; -pumpe, die 'Gerät, mit dem Luft od. andere Gase in einen od. aus einem Hohlraum gepumpt wird' ( $>$ TABL Fahrzeuge): mit der $\sim$ das Fahrrad aufpumpen; 4 Pumpe, -raum, der biet der $\mathrm{L}$ (boheit' biet der Lufthoheit': den $\sim$ verletzen, verlassen
$>$ Raum; -röhre, die 'röhrenförmige Verbindung zwischen Kehlkopf und Lunge, durch die die Luft beim Atmen in die Lunge gelangt'; ' FELD I.1.1: von der Nahrung ist etwas in die $\sim$ gelangt ${ }^{\prime}>$ Rohr, -schirf, das 'durch Motoren angetriebenes lenkbares, langsam fliegendes Luftahrzeug, das hälter und daran befestigten Gondeln (2) zum Transport (1) von Passagieren und Fracht besteht'; $>$ FELD VIII.4.2 * $>$ Schiff; -schloss, das 'etw. Wunderbares, etw., das man sich wünscht, das aber nur in der Phantasie existiert': das ist nicht zu verwaven ('Pl bauen ('Pläne machen, die unrealistisch sind und
sich nicht verwirklichen lassen'); -streitkräfte, die $\langle$ Pl. ' 'Teil der Streitkräfte, der militärische Operationen, Kampfhandlungen unter Einsatz von Luftfahrzeugen durchführt'; SYN Luftwaffe: die kommen zum Einsatz $*>$ streiten, > Kraft Lüftung ["lyft..], die; $\sim, \sim$ en 1.1. (vorw. Sg.) 'das Luften (1): fur gute $\sim$ sorgen; die $\sim$ im Zimmer ist moderne $\sim$ einhauen: die $\sim$ des Hauses fiultioniert moderne $\sim$ einbauen, die $\sim$ des
nicht richtig, ist defekt $\$>$ Luft Luft ['luft]|-waffe, die SYN 'Luftstreitkräfte' * > Waffe; -zug, der $\langle$ o.Pl. $\rangle$ 'Bewegung der Luft, leichter Wind': ein leichter, kühler $\sim$; durch den $\sim$ bewegten
sich die Zweige, Blätter, Gardinen $\$>>$ ziehen

\section{Example 6: Wörterbuch Deutsch als Fremdsprache}

If a learner uses WDAF in order to find the meaning of the compound "Luftpumpe" he/she will experience problems with respect to the outer access structure. The consultation process starts at the lemma "Luft", continues to "Luft/luft" without success, while a third "Luft" and a fourth "Luft/luft" also do not provide the solution. Furthermore, the search route of the learner is interrupted by the alphabetical placing of "lüften", "lüftig" and "Luftikus". At long last the required sublemma is found in the fifth article. For a detailed discussion about the problems of nesting and multiple niching consult Gouws (2001: 106-107). 
In the users' guidelines of the Target English Learner's Dictionary, it is stated that only derivates are treated as sublemmata. However, two derivatives, namely "ending" and "endless", are treated as separate lemmata instead of being treated as sublemmata in the article of "end". Many other examples illustrating similar inconsistencies can be found. The lexicographer needs to place and treat sublemmata consistently so that users can find and retrieve the information.

The outer access structure can be enhanced by the use of typographical devices, for instance, the bold printing of lemmata helps the user in his/her search for a particular lemma in the word list. Lemmata can also be indented or protruded thereby being more conspicuous and identifiable. Typographical devices acting as structural indicators of homonyms also form part of the outer access structure.

Decisions about the placement of multiword units and collocations also have implications for the outer access structure and consequently the accessibility of the dictionary. Multiword units and collocations will not be discussed further, but the following comment can suffice: depending on the level of the learner and the function of the dictionary, these data categories should be organised according to a consistent, transparent system which will enhance access to the data.

\subsection{Outer rapid access structure}

The last part of the outer access structure consists of the outer rapid access structure. To speed up access in the word list, structural indicators are usually used to separate the different word list sections. According to Hausmann and Wiegand (1989: 335), these bold face capitals A, B ... Z represent the access alphabet of the dictionary. These non-typographical structural indicators can be supported by a thumb index on the outside of the dictionary page. It forms part of the outer rapid access structure giving quick access to the pages dealing with the letter or letters in question. The outer access structure is continued in the running heads of each page. They are guiding elements which consist of one or more words or parts of words at the top of each page.

Different dictionaries employ different systems of running heads, for instance OALD gives the first lemma of the left page and the last lemma of the right page. A clearer indication of the scope of a page forms part of a userfriendly approach. In the Cambridge Learner's Dictionary the space reserved for running heads is used to explicate an important non-typographical structural marker. The user thereby has rapid access to specific information without having to page to the users' guidelines for clarification.

A further element of the outer access structure which contributes to a rapid detection of different dictionary parts is coloured pages or edges of pages. In a bilingual learner's dictionary these pages can divide the two main parts of the dictionary, whereas in a monolingual learner's dictionary they can indicate study pages, minigrammars or illustration leaflets/plates. 


\subsection{Conclusion}

Lexicographers have to provide an innovative and creative outer access structure to facilitate the outer search route of the learner. Decisions regarding the outer access structure must be explained and illustrated in the front matter. Lexicographers have various options to improve the outer access structure of the dictionary. Gouws (1996: 21) sums it up as follows: "On the one hand, the lexicographer could add special entries or alter the presentation of macrostructural elements and on the other hand, the lexicographer could include additional access structures to create a poly-accessible dictionary." An example of a dictionary employing an innovative outer access structure is the Kenkyusha's Lighthouse English-Japanese Dictionary where structural markers indicate the usage frequency of the lemmas. Furthermore, the core vocabulary is presented in colour and a bigger type face. It is especially useful for the beginner because core vocabulary can be identified at a glance.

\section{The inner access structure}

A second main component of the access structure of a dictionary is the access structure of the microstructure or the internal access structure. The user's internal search route starts at the lemma and continues into the dictionary article. Svensén (1993: 16) describes the internal search route of the user as follows: "When the right entry word has been found, the user also has to find the right section within the entry, and within that section the material is grouped in a certain order and presented according to certain conventions, which can be fairly difficult to learn."

\subsection{Data distribution structure}

The strategic placement of data in the dictionary article is determined firstly by the data distribution structure. The design of a data distribution structure and data distribution program must form part of the dictionary plan. Bergenholtz and Tarp (1995: 188) describe the distribution structure as the structure of linguistic (and encyclopaedic) information distributed across or occurring in different places in the dictionary. Basically, this information may occur in three different places: in the individual articles, in different types of framed articles or in separate components like a dictionary grammar. The inner access structure also refers to the form and ordering of data in the dictionary article. In this regard Opitz (1983: 174) demands the following: "In order to prove successful, user convenience must receive high priority. This includes first of all the choice of a type of type style that can be deciphered even under such adverse conditioning as poor lightning, haste and fatigue. Next come matters of organisation: how to allow for fast scanning of an entry in order to find a particular item of information while avoiding mistakes and confusion, or even irritation, on the user's part." 


\subsection{Micro-architecture}

A dictionary article should also display a micro-architecture. According to Wiegand (1996: 143), the micro-architecture "aids the reception of this mode of presentation so that dictionary articles which are arranged in this manner are user-friendlier than articles which lack a micro-architecture". The following articles illustrate the lack and occurrence of micro-architecture.

\begin{abstract}
Moos, das; -es, -e 1. kleine, in großer, dicht stehender Menge, vorzugsweise an schattigen, feuchten Stellen wachsende immergrüne, sich durch Sporen vermehrende Pflanze: weiches, grünes M.; Moose und Flechten; sich im Wald ins M., auf das M. setzen - 2. /o. Pl./ umg. Geld (1): da muß doch eine Masse M. herausspringen
\end{abstract}

Example 7: Article without micro-architecture

Moos, das; es, -e

1. kleine, in großer, dicht stehender Menge, vorzugsweise an schattigen, feuchten Stellen wachsende immergrüne, sich durch Sporen vermehrende Pflanze; weiches, grünes M.; Moose und Flechten; sich im Wald ins M., auf das M. setzen.

2. /o. Pl./ umg. Geld (1): da muß doch eine Masse M. herausspringen.

Example 8: Article with micro-architecture

The conventional linear presentation of data types in example 7 makes it difficult for the user to retrieve the information and the process also takes longer. In example 8 the data types are clearly separated, also by the use of space, and the polysemes are placed under one another. The internal search route of the second article is facilitated by the finely planned micro-architecture. Every microstructural element must have a function and place in the dictionary article and it must be presented in an unambiguous way so that the information can be retrieved easily and rapidly.

The micro-architecture of dictionary articles also implies that all the different microstructural elements have to be employed in an interactive relation to one another. The different microstructural categories should complement each other without increasing the degree of textual condensation in the article. It is therefore of great importance that the lexicographer already decides on the design and well-structured micro-architecture of the article during the planning stages in order to assist the user when he/she is negotiating the article internal search route. The lexicographer can use a lay-out sample with specimen articles to make sure that the micro-architecture leads to user-friendliness and readability. 


\subsection{Order of data types in the microstructure}

Another aspect of the inner access structure is the order in which data types are presented. According to Gouws (1993: 37), the hierarchical character of the microstructure gives prominence to the first entries and gives them a position of major focus, whereas the last entries receive far less focus. This should influence the organisation of information in the dictionary. Being familiar with the specific typological criteria, a lexicographer knows what the priority of his/her dictionary is and which entry should receive the most emphasis. The lexicographers of TAW deem the translation equivalents, followed by the example material, as the most important data categories in the dictionary article. Consequently these entries are placed at the beginning of the article in the focus position. On the other hand, parts of speech are indicated at the end of the article. Because the ordering of the data categories in this dictionary deviates from the traditional placing, it is marked with a structural marker, namely a square.

\subsection{Data-architecture}

One of the problems users experience on their internal search is the unclear division between data categories. This problem can be solved, firstly by using a well-developed micro-architecture, thereby incorporating white spaces. A second solution is to distinguish between different search zones by using typographical structure indicators, for example semibold, italic, normal, capital letters, etc. Although they are not functional text segments but attributes of the data form, they indicate boundaries between different search zones. Decisions about the typographical structure indicators or markers form part of the dataarchitecture of the article. It requires that the lexicographer actively participate in the layout of articles in order to create unambiguously defined data units which enhance the access to information. The data-architecture should also help to create a coherent and integrated article. Examples 9.1 and 9.2 illustrate the effect of typographic structural markers or the lack thereof on the easy retrieval of information.

An important fact to keep in mind when planning the data-architecture, as with any other aspect of a learner's dictionary, is to guard against the excessive varying of the structural indicators which can hinder readability and complicate the internal search route.

\footnotetext{
gek, (s) (-ke), fool, madman, booby; ke en DWASE skryf hulle name op deure en glase, fools' names and donkeys' faces are to be seen in public places; a white wall is a fool's paper; elke het sy GEBREK, every rose has its thorn; every bean has its black; iem. vir die HOU, make a fool of someone; die -ke kry die KAARTE, fortune favours fools; staan en $K Y K$ soos ' $n$, stare like an idiot; dit is nog LANK nie so $\sim$ nie, it is not a bad idea; iem. vir die
} 


\begin{abstract}
$\sim$ laat $L O O P$, send someone on a fool's errand; die $\sim$ SKEER met iem., make a fool of someone; so= veel WERD as 'n $\sim$ daarvoor wil gee, it is worth as much as a fool would give for it; een $\sim$ kan meer vrae vra as wat 'n honderd WYSES kan beantwoord. one fool can ask more questions than ten wise men can answer; (w) (ge-), play the fool; (b, bw) ([-ke]; -ker, -ste), foolish, mad, queer, crazy, fond (of); wees van $A N G S$, be frantic with anxiety; $\sim G E=$ $N O E G$, sy ..., oddly enough she ...; $\sim n a s y$ KIND wees, dote on his child; dis te $\sim$ om LOS te loop, that is most absurd; it does not bear thinking of; nie so as wat hy LYK nie, he is not as green as he is cabbage-looking; iem. $\sim$ MAAK, drive a person crazy; NA, mad about (on); jou SOEK, hunt high and low; die $\sim$ ste van die TOESTAND, the oddest feature of the situation; $\sim$ na VIS wees, be very partial to (fond of) fish; van WOEDE mad with rage; $\sim W O R D$, go mad.
\end{abstract}

Example 9.1: Pharos: punctuation gek $^{1}$ fool Only a fool would leave his car with the keys still in it. Net 'n gek sou sy motor verlaat met die sleu= tels nog daarin. $\square$ gek selfstandige naamwoord (meervoud gekke)

gek $^{2}$ - foolish, silly, stupid It is foolish/silly/stupid to go too deep into the sea if you can't swim. Dit is gek om te diep in die see in te gaan as jy nie kan swem nie. 2 mad "Let's go for a ride on our bicycles." - "Are you mad? It's raining!" "Kom ons gaan ry 'n ent op ons fietse." - "Is jy gek? Dit reën!"

- gek maak drive mad That dog will drive me mad with its barking! Daardie hond sal my nog gek maak met sy geblaf!

$\square$ gek byvoeglike naamwoord (attributief $\mathbf{g e k}$ ) gek= ker, gekste

Example 9.2: TAW: punctuation + structural markers

\subsection{Inner texts}

Usage notes are an important inner access structure, which is employed in most learner's dictionaries. These inserted inner texts are especially appropriate for learner's dictionaries. They can easily be distinguished from the rest of the article, because they are presented in a different manner, e.g. in boxes or tables. If the lexicographer wants to draw the attention of his intended target user to a specific aspect of a lemma, the inclusion of an inserted inner text will be a clear milestone on the search path of the inner access structure. The lexicographer has to decide on a system for the placing of usage notes, either after a specific data type, or at the end of the article.

\subsection{Inner rapid access structure: data-exposure structure}

The use of non-typographical structural markers is a last method of indicating and marking borders between data categories in order to enhance the inner rapid access structure. They are used firstly to mark different polysemous senses of a lemma. The effect of a grouped polysemy in example (7) compared with an ungrouped polysemy in example (8) is evident.

Example 7 shows senses which are presented in succession and lead to a horizontal, user-unfriendly search route. In example 8 all the senses are grouped under one another, in vertical text blocks, which are easy to distinguish and form part of the inner access structure.

Explicit non-typographical indicators marking specific data categories form part of the article internal data-exposure structure. These inner rapid access structures expose the presented data and allow the user a faster access in 
the data look-on. The data-exposure program of dictionary articles, especially in a learner's dictionary, should be clear and transparent. If not, the user has to be familiar with the inner structure of the articles in the dictionary and with the order of the article positions.

\subsection{Conclusion}

Renovation in present-day learner's dictionaries focuses particularly on the inner access structures and rapid inner access structures. In many cases, these changes increased the quality of the dictionary, but it can also lead to an increased text density. This special balance that must be maintained is expressed as follows by Svensen (1993: 16): "It is not merely the information needs of different categories of users that are of importance. An equally important factor is their ability to find and make use of the information given. Here the lexicographer is forced into a difficult balancing act. On the one hand, the dictionary must contain as much information as possible without becoming unnecessarily bulky. On the other hand, this information must not be so compressed that the intended user will not be able to utilise it."

\section{Meta-access structure}

A third and last aspect of the access structure which will not be addressed in this article is the meta-access structure. This refers to the language in which data is presented. Hausmann and Wiegand (1989: 341) argue that from one and the same lexicographic data unit or treatment unit two different users may reconstruct different information. In order for the user to extract this information the language usage should match the target user group of the dictionary. Therefore the language used in the front and back texts of the dictionary as well as definitions, examples etc. should be accessible. The metalanguage should therefore also help the user to retrieve information as easily and rapidly as possible.

\section{Three important questions}

When the access structure in learner's dictionaries are considered, as is the case in this article, certain questions immediately arise.

1. What is the use of the access structure in general?

2. Is there a difference between the access structure of general dictionaries and learner's dictionaries?

3. Do different levels of learners affect the access structure? 


\subsection{Question one}

As already explained, the access structure can be viewed as the form in which content is presented. Without an accessible form, data presented and arranged in the macro-, micro-, frame and distribution structures cannot be accessed and employed by the user. The failure of dictionary consultation procedures is often attributed to the inadequate reference skills of the users, in this case learners. But it is more often than not the structure of the dictionary that impedes the user from sufficient access to data. According to Gouws (2001: 102), the rapid and unimpeded access of the users to the relevant data presented in the dictionary has to be regarded as a prerequisite for a successful lexicographic product in a user-driven approach. The ease with which macro- and microstructural information is located and retrieved determines the quality and accessibility of the presentation. The lexicographer can therefore use the access structure as primary instrument to ensure the user-friendliness of a dictionary.

\subsection{Question two}

Different outer texts in different dictionaries suggest that the outer access structure of a dictionary is designed with a specific user in mind. In most comprehensive and standard dictionaries, the outer search route will start at the cover, possibly continue to the table of contents, the running heads and the thumb index and end at the desired lemma. Recently learner's dictionaries have employed certain bridge texts to facilitate and enhance the outer search route of the dictionary. These integrated outer texts are additional wordlists or equivalent registers, found mostly in learner's dictionaries for beginners. They help the user with a restricted knowledge of the language and specifically the spelling of a foreign language word to reach the lemma via a mother tongue equivalent. An equivalent register enables the learner to reach the unknown word with the aid of a translation and thus enhances text reception and production in the foreign language. In the same manner as the users' guidelines, an outer text presenting an equivalent register should be regarded as a compulsory text in monolingual and monoscopal bilingual learner's dictionaries for beginners and intermediate learners. If the learner reaches the advanced stage, where thinking in the foreign language becomes a possibility, the need for this special outer text decreases.

In the Passport English Hebrew Learner's Dictionary, the equivalent register is given the status of a Hebrew-English dictionary or "reverse dictionary" that also "forms an integral part of the dictionary in order to enable the learner to locate the English headword" (p. viii).

It is also evident that the inner access structure varies according to the dictionary type. If one examines articles from different dictionaries it would not be difficult to decide what dictionary type they represent. It is not only the 
amount and density of data that lead one, but the internal structure of the articles also suggests that different dictionary types have different inner access structures to correlate with specific users.

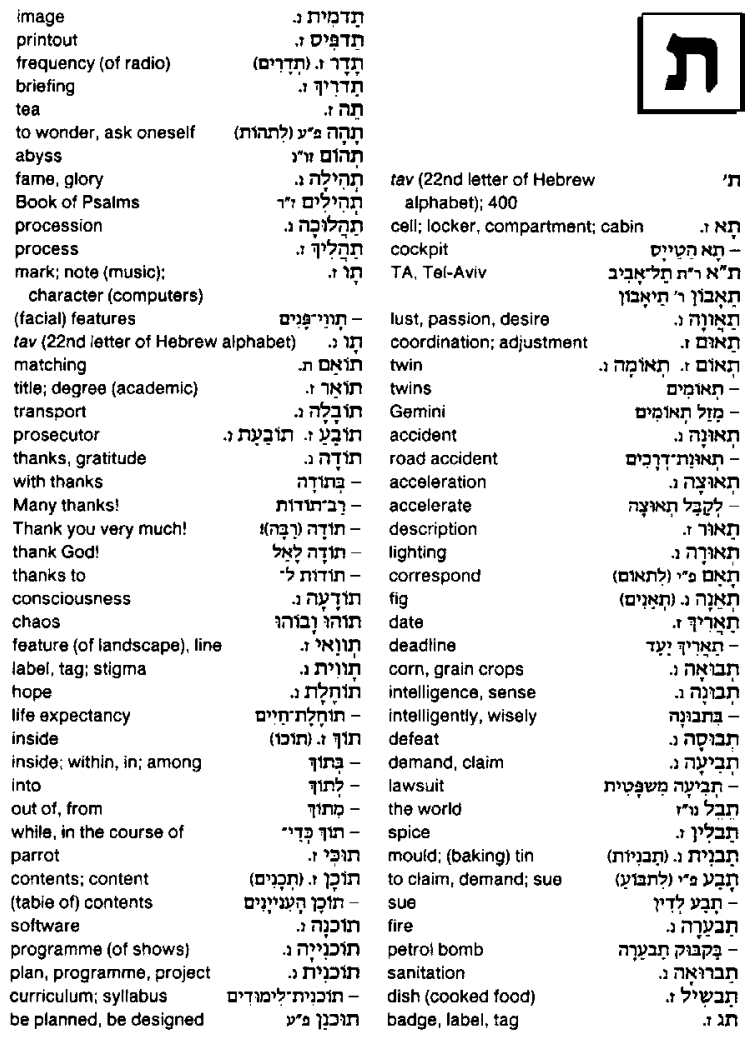

Example 10: An equivalent register in Passport

A comprehensive dictionary, such as the WAT, has a sophisticated user in mind and consequently only a few extra indicators facilitate the search route of the user within complex dictionary articles. The structure of articles from a standard Afrikaans dictionary, HAT, also suggests a user with developed/ adequate reference skills. Some typographical and non-typographical markers indicate the borders between different data categories. The Cambridge Learner's Dictionary uses a sophisticated access structure, designed to help the learner to overcome possible obstacles, whether it be because of language level or lack of reference skills in the search for specific data. Boundaries between all data categories are marked, polysemes are distinguished through guide words and illustrations help the user with immediate knowledge transfer. 


\subsection{Question three}

The third important question related to the topic is whether different levels of learners affect the access structure of learner's dictionaries. The following graphs will illustrate the possible relationship between the levels of learners and the outer and inner access structure. If one groups together the different outer access structures, as presented in existing learner's dictionaries, they fall into three categories. Firstly there are those structures that are compulsory, such as the alphabetical order, the access alphabet, running heads and the users' guidelines in the front text. Secondly some dictionaries also have a few optional structures in order to enhance access to the macrostructure. These optional structures are thumb indexes, coloured pages and some outer texts. Lastly some learner's dictionaries for beginners also add bridge texts (as illustrated previously) to assist the beginner in finding the required lemma via the mother tongue.

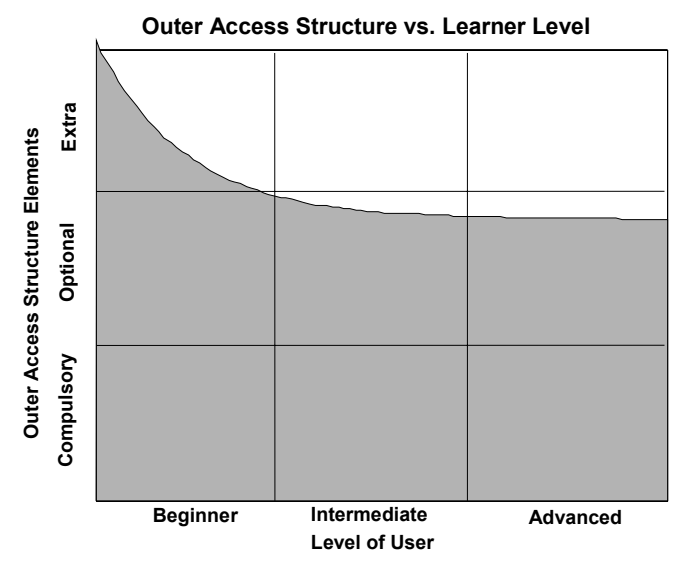

The horizontal axis of the graph represents the learners' levels and the vertical axis the three groups of outer access structures. The graph shows a decline in the number and type of outer structures in relation to the level of user. At beginner's level, the user needs as much help as possible to facilitate the outer search route.

There is no distinction between learner's dictionaries with a function of production in the foreign language and reception of the foreign language, because it would not influence the outer access structure directly. A learner's dictionary designed for the purpose of reception might have a larger macrostructure with more lemmata than one for production. On this graph the lines indicating production and reception therefore fall together.

In the case of the inner access structure of learner's dictionaries, the distinction between dictionaries for production and reception does have an influ- 
ence on the number of inner access structures. The three categories of inner access structures are the following. The first contains implicit inner access structures being the data distribution structure and the order of the data types. The second category comprises explicit compulsory access structures, including data-architecture and micro-architecture. The third contains explicit optional rapid access structures, inner texts and data exposure structures.

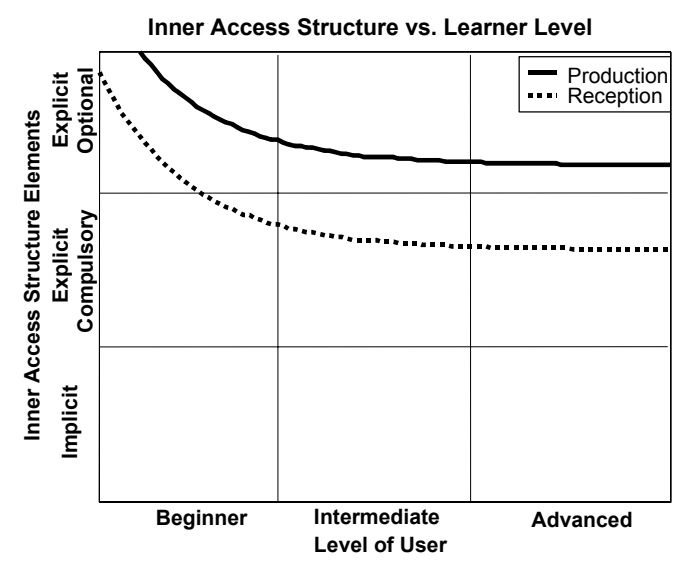

The second graph also indicates a decline in inner access structural elements in relation to the specific category of learner. In this case, however, a distinction between the productive and receptive modes appears. Lexicographers of dictionaries with production in the foreign language as dictionary function need to add extra data in order to enable the learner to use it actively. These data categories, like the indication of frequent collocations and proverbs, and the inclusion of syntactical combination principles etc. demand more explicit structural elements than is the case with dictionaries designed for reception.

\section{Conclusion}

The access structure functions as primary structure in guiding the user during the consultation process. The user's search problem can be solved swiftly and easily if the access structure of a dictionary, specifically a learner's dictionary, is developed and applied accurately. Existing learner's dictionaries, as shown in this article, include new outer texts and subtexts to explicate specific data. They also employ innovative strategies of presenting data in dictionary articles. However, most learner's dictionaries lack a well-developed access program that guides the user along every step of the search route. In this article, some suggestions have been made and illustrated in order to improve the access profile of learner's dictionaries. 


\section{References}

\section{Dictionaries}

Crowther, J. et al. (Eds.). 19955. Oxford Advanced Learner's Dictionary. Oxford: Oxford University Press.

Du Plessis, M. 1998. Tweetalige Aanleerderswoordeboek/Bilingual Learner's Dictionary. Cape Town: Pharos Woordeboeke.

Eksteen, L.C. 199714. Pharos Groot Woordeboek/Major Dictionary. Cape Town: Pharos Woordeboeke.

Gefen, R. et al. (Eds.). 1996. Passport English Hebrew Learner's Dictionary. Jerusalem: Kernerman Publishing.

Gillard, P. (Ed.). 2001. Cambridge Learner's Dictionary. Cambridge: Cambridge University Press.

Kempcke, G. et al. (Eds.). 2000. Wörterbuch Deutsch als Fremdsprache. Berlin: Walter de Gruyter.

Odendal, F.F. et al. (Eds.). 1994. Verklarende Handwoordeboek van die Afrikaanse Taal. Johannesburg: Perskor.

Rundell, M. et al. (Eds.). 2002. Macmillan English Dictionary for Advanced Learners. London: Bloomsbury Publishing.

Sinclair, J.M. (Ed.). 1996². Collins COBUILD Learner's Dictionary. London: HarperCollins.

Summers, D. (Ed.). 1984. Target English Learner's Dictionary. Cape Town: Maskew Miller Longman.

Summers, D. (Ed.). 1995³. Longman Dictionary of Contemporary English. Harlow: Longman.

Takebayashi, S. and Y. Kojima (Eds.). 19902. Kenkyusha's Lighthouse English-Japanese Dictionary. Tokio: Kenkyusha.

Van Schalkwyk, D.J. (Ed.). 1996. Woordeboek van die Afrikaanse Taal, Part X. Stellenbosch: Bureau of the WAT.

\section{Other literature}

Almind, R. and H. Bergenholtz. 2000. Die ästhetische Dimension der Lexikographie. Fix, U. and H. Wellmann (Eds.). Bild im Text - Text und Bild: 259-288. Heidelberg: C. Winter.

Béjoint, H. 1994. Tradition and Innovation in Modern English Dictionaries. Oxford: Clarendon Press.

Bergenholtz, H. and S. Tarp (Eds.). 1995. Manual of Specialised Lexicography. Amsterdam/Philadelphia: John Benjamins.

Bolinger, D. 1985. Defining the Indefinable. Ilson, R. (Ed.). 1985. Dictionaries, Lexicography and Language Learning: 69-73. Oxford: Pergamon Press.

Gouws, R.H. 1993. Afrikaans Learner's Dictionaries for a Multilingual South Africa. Lexikos 3: 29-47.

Gouws, R.H. 1996. Bilingual Dictionaries and Communicative Equivalence for a Multilingual Society. Lexikos 6: 14-31.

Gouws, R.H. 2001. The Use of an Improved Access Structure in Dictionaries. Lexikos 11: 101-111.

Gouws, R.H. 2002. The Outer Texts in the De Gruyter Wörterbuch Deutsch als Fremdsprache. Wiegand, Herbert E. (Ed.). 2002. Perspektiven der pädagogischen Lexikographie des Deutschen II: 471-484. Tübingen: Max Niemeyer.

Hausmann, F.J. and H.E. Wiegand. 1989. Component Parts and Structures of General Monolingual Dictionaries: A Survey. Hausmann, F.J., O. Reichmann, H.E. Wiegand and L. Zgusta (Eds.). 1989-1991. Wörterbücher. Ein internationales Handbuch zur Lexikographie/Dictionaries. An International Encyclopedia of Lexicography/Dictionnaires. Encyclopédie internationale de lexicographie: 328-360. Berlin: Walter de Gruyter. 
Kammerer, M. and H.E. Wiegand. 1998. Über die textuelle Rahmenstruktur von Printwörterbüchern. Präzisierungen und weiterführende Überlegungen. Lexicographica 14: 224-238.

Opitz, K. 1983. The Terminological/Standardised Dictionary. Hartmann, R.R.K. (Ed.). 1983. Lexicography: Principles and Practice: 163-180. London: Academic Press.

Stark, M. 2001. Die toegangstruktuur in verklarende aanleerderwoordeboeke. Unpublished M.A. Thesis. Stellenbosch: University of Stellenbosch.

Svensén, B. 1993. Practical Lexicography: Principles and Methods of Dictionary-Making. Oxford: Oxford University Press.

Tono, Y. 1992. The Effect of Menus on EFL Learners' Look-up Processes. Lexikos 2: 230-253.

Wiegand, H.E. 1996. A Theory of Lexicographic Texts: An Overview. Suid-Afrikaanse Tydskrif vir Taalkunde 14(4): 134-149.

Wiegand, H.E. 1998. Wörterbuchforschung. Untersuchungen zur Wörterbuchbenutzung, zur Theorie, Geschichte, Kritik und Automatisierung der Lexikographie. 1. Teilband. Berlin/New York: Walter de Gruyter. 